\title{
PERAN QUALITY CONTROL DAN TOTAL QUALITY MANAGEMENT DALAM PENGEMBANGAN LEMBAGA PENDIDIKAN
}

Oleh: Suparman

Dosen STAIMS Yogyakarta

\begin{abstract}
Holding a quality education be the desire of every educational institution. Realizing quality education institutions require processes and stages consistently must be passed by all academic faculty. Advancing educational institutions is a shared task is not an individual task or leadership.

Required proper methods in order to systematically educational institutions can be a quality institution. Improved quality of institutions run continuously so that participation and society's expectations of education which are becoming increasingly powerful.

Quality control and total quality management is a method to provide assurance to the public about the quality of education held by the institution. Continously improvement aktivityis evidence of the seriousness in presenting quality educational institutions through quality control and total quality management.
\end{abstract}

\begin{abstract}
Abstrak
Menyelenggarakan pendidikan yang bermutu menjadi keinginan setiap lembaga pendidikan. Mewujudkan lembaga pendidikan yang bermutu memerlukan proses dan tahapan yang secara konsisten harus dilalui oleh segenap sivitas akademik. Memajukan lembaga pendidikan adalah tugas bersama bukan tugas individu atau pimpinan.

Diperlukan metode yang tepat agar lembaga pendidikan secara sistematis dapat menjadi lembaga yang bermutu. Peningkatan mutu lembaga berjalan secara terus menerus agar partisipasi dan ekspektasi masyarakat terhadap lembaga pendidikan yang dikelola menjadi semakin kuat.

quality control dan total quality managementmerupakanmetode untuk memberikan jaminan kepada masyarakat akan mutu pendidikan yang diselenggarakan oleh lembaga. Continously improvement aktivity merupakan bukti dari kesungguhan dalam menghadirkan lembaga pendidikan yang bermutu melalui quality control dan total quality management.
\end{abstract}

\section{A. Latar Belakang}

Pendidikan merupakan dasar dari segala peradaban dan kemajuan. Setiap negara yang memiliki peradaban dan kemajuan sebagian besar disebabkan karena telah mengalami kemajuan terlebih dahulu pada bidang pendidikan.Hasil penelitian memperlihatkan adanya hubungan yang signifikan dan positif antara tingkat pendidikan dengan kehidupan ekonomi, dalam 
arti makin tinggi derajat pendidikan makin tinggi pula derajat kehidupan ekonomi ${ }^{1}$.Kehidupan ekonomi yang meningkat merupakan salah satu indikator dari kemajuan peradaban suatu bangsa.

Kebijakan pemerintah untuk meningkatkan mutu pendidikan di Indonesia khususnya untuk meningkatkan mutu pembelajaran para pendidik adalah adanya sertifikasi guru maupun sertifikasi dosen.Kedudukan dosen sebagaimana tertulis dalam UU guru dan dosen adalah sebagai tenaga profesional berfungsi untuk meningkatkanmartabat dan peran dosen sebagai agen pembelajaran, pengembang ilmu pengetahuan, teknologi, dan seni, sertapengabdi kepada masyarakat berfungsi untuk meningkatkan mutu pendidikan nasional ${ }^{2}$.Ketentuan ini memberikan makna bahwa setiap pendidik yang telah bersertifikat harus dapat memberikan layanan pendidikan secara berkualitas, akan tetapi sebagian besar pendidik masih memiliki persepsi bahwa sertifikasi pendidik dipahami baru sebatas peningkatan kesejahteraan dan belum diimbangi oleh peningkatan mutu layanan pendidikan ${ }^{3}$.

Suzanne yang menegaskan bahwa pendidikan memiliki tiga pilar utama yaitu suatu proses kontruksi aktif, meningkatkan jumlah pengetahuan dan bagaimana menggunakan pengetahuan ${ }^{4}$. Apabila tiga pilar ini dapat diwujudkan oleh setiap pendidik, maka dengan sendirinya mutu layanan pendidikan akan semakin meningkat, dengan kata lain bahwa memberikan layanan pendidikan yang bermutu adalah suatu keharusan bagi insan pendidik. Meningkatnya mutu pendidikan akan diimbangi dengan meningkatnya kesejahteraan dan peradaban suatu bangsa.

Tulisan ini berusaha untuk memberikan wacana secara operasional bagaimana cara seorang pendidik (educator) dapat memiliki layanan

\footnotetext{
1 Didin Saripudin. Pembangunan Prndidikan dan Pertumbuhan Ekonomi Indonesia. Makalah disajikan dalam International Seminar on Lifelong Education (ISLE), Tanggal 22-23 Agustus 2008 di Universitas Pendidikan Indonesia, Bandung. hlm 1.

${ }^{2}$ Undang-undang No 14 Tahun 2005 tentang Guru dan Dosen, pasal 5.

${ }^{3}$ Hasbullah. Guru Bersertifikasi Versus Profesionalisme Guru : Tinjauan Kritis Terhadap Pelaksanaan Sertifikasi Guru. Jurnal Pendidikan Teknik Elektro. UPI Bandung. 2010.

${ }^{4}$ Suzanne M Wilson \& Penelope L Peterson. Theories of Learning and Teaching What Do They Mean for Educators?. National Education Assosiaton. Washington DC. hlm 1. 2006.
} 
pembelajaran yang berkualitas serta bagaimana menjaga kualitas pembelajaran tersebut agar dapat berlangsung secara berkesinambungan.

\section{B. Quality Control}

Istilah quality controlmuncul pada awal tahun 1950 dan mulai dikenal publik secara luas sekitar tahun $1980^{5}$, semula istilah ini berhubungan dengan dunia industri untuk mempertahankan mutu agar dapat memenangkan persaingan sehingga dapat terjadi keberlangsungan proses produksi. Perkembangan zaman dan kemajuan teknologi menyebabkan istilah quality controltidak hanya dipakai pada dunia industri akan tetapi digunakan pada setiap bidang yang berorientasi pada mutu layanan, termasuk dalam hal ini adalah bidang pendidikan.

Secara harfiah quality control adalah proses yang terlibat dalam sistem untuk memastikan manajemen pekerjaan, kompetensi dan kinerja selama pembuatan produk atau layanan sehingga dapat memenuhi rencana mutu sebagaimana yang telah dicanangkan ${ }^{6}$. Sesuai dengan pendapat di atas dapat dimengerti bahwa quality controlmerupakan bagian dari manajemen untuk menjamin bahwa produk yang berupa barang dan jasa dipastikan memiliki mutu yang terjamin sehingga masyarakat memiliki kepercayaan akan kualitas barang dan jasa tersebut. Pada konteks pendidikan adalah layanan jasa dari pendidik pada saat menyelengarakan pembelajaran.

Scottish Qualifications Authority (SQA), adalah lembaga yang memiliki otoritas untuk menentukanmutu suatu produk layanan maupun jasa (termasuk dalam hal ini adalah jasa layanan pendidikan) menyarankan cara melakukan quality control ${ }^{7}$.

Tabel 1 : Kriteria Umum Menjaga Kualitas Barang dan Jasa

\begin{tabular}{|c|c|c|c|}
\hline No & Kriteria & Standar SQA & Pusat Perhatian \\
\hline 1 & Bagian yang & a. Selalu memperhatian & a. Melihat kembali dan \\
\hline
\end{tabular}

${ }^{5}$ https://www.isixsigma.com. hlm 1.

${ }^{6} \mathrm{http}: / /$ www.qualitygurus.com/courses/mod/forum/discuss.php?d=1557

${ }^{7}$ Scottish Qualifications Authority. Quality AssurancePrinciples, Elements and Criteria. Published by the Scottish Qualifications Authority. 1998. hlm. 10. 


\begin{tabular}{|c|c|c|c|}
\hline & $\begin{array}{l}\text { selalu ditinjau } \\
\text { dan terus } \\
\text { ditingkatkan }\end{array}$ & $\begin{array}{l}\text { jaminan mutu dan } \\
\text { memiliki informasi } \\
\text { terbaru mengenahi } \\
\text { kebutuhan masyarakat } \\
\text { terhadap barang dan } \\
\text { jasa yang dihasilkan } \\
\text { b. Bertanya kepada } \\
\text { pengguna untuk } \\
\text { mengetahui umpan } \\
\text { balik }\end{array}$ & $\begin{array}{l}\text { dapatkan informasi } \\
\text { terbaru yang diperlukan } \\
\text { secara internal. } \\
\text { b. Mengidentifikasi peran } \\
\text { dan tanggungjawab } \\
\text { staf/bawahan } \\
\text { c. Permudah bawahan untuk } \\
\text { berkonsultasi, berlatih } \\
\text { dan memberikan umpan } \\
\text { balik }\end{array}$ \\
\hline 2 & $\begin{array}{l}\text { Menyiapkan } \\
\text { informasi } \\
\text { produk barang } \\
\text { dan jasa serta } \\
\text { panduan } \\
\text { kepada } \\
\text { Mayarakat luas }\end{array}$ & $\begin{array}{l}\text { Menentukan } r \text { target } \\
\text { kepada siapa informasi } \\
\text { dan panduan produk } \\
\text { diberikan }\end{array}$ & $\begin{array}{l}\text { Perluas informasi yang } \\
\text { diperlukan kepada setiap } \\
\text { bawahan, pengguna dan } \\
\text { calon pengguna }\end{array}$ \\
\hline 3 & $\begin{array}{l}\text { Membuat } \\
\text { penilaian } \\
\text { khusus yang } \\
\text { diperlukan } \\
\text { kepada calon } \\
\text { pengguna }\end{array}$ & $\begin{array}{l}\text { a. Sediakan panduan dan } \\
\text { informasi sebaik } \\
\text { mungkin (secara } \\
\text { khusus) kepada para } \\
\text { calon pengguna } \\
\text { b. Berikan kesempatan } \\
\text { secara fair dan } \\
\text { konsisten kepada } \\
\text { calon pengguna untuk } \\
\text { memutuskan }\end{array}$ & $\begin{array}{l}\text { Carilah penilaian atau } \\
\text { pendapat dari pengguna } \\
\text { yang baik tentang produk } \\
\text { yang dihasilkan kemudian } \\
\text { terapkan untuk menjamin } \\
\text { mutu produk. }\end{array}$ \\
\hline 4 & $\begin{array}{l}\text { Proses yang } \\
\text { akurat dan } \\
\text { tepat waktu }\end{array}$ & $\begin{array}{lr}\text { a. } & \text { sencatat } \\
\text { lengkap } & \text { hasil dari } \\
\text { interaksi } & \text { dengan }\end{array}$ & $\begin{array}{l}\text { a. Berilah no seri pada } \\
\text { setiap produk yang telah } \\
\text { dijamin mutunya }\end{array}$ \\
\hline
\end{tabular}




\begin{tabular}{|l|l|c|c|}
\hline & \multicolumn{2}{|c|}{ pengguna } & b. Masukkan dan perbarui \\
b. Membahas secara & data secara periodik \\
periodik data-data & \\
pengguna & & \\
\hline
\end{tabular}

Cara di atas merupakan salah satu prosedur umum untuk mengetahui mutu dari barang maupun jasa yang dihasilkan. Masih ada beberapa cara yang lain, akan tetapi yang paling penting untuk disadari adalah selaku penghasil produk atau lembaga penghasil jasa, apabila tidak dapat memberikan jaminan mutu terhadap out-put yang dihasilkan maka akan berakibat pada menurunnya bahkan hilangnya produk tersebut dari pasar. Menjaga produk agar tetap memiliki eksistensi di pasar dapat dilakukan dengan menerapkansistem manajemen mutu secara berkesinambungan agar hasilnya dapat selalu meningkat secara kualitatif, hal ini dikenal dengan istilah continously quality improvement, yang berimplikasi pada setiap bidang.

Implikasi dalam bidang pendidikan dapat dipaparkan secara logis yakni apabila lembaga penyelenggara pendidikan, yang dalam hal ini termasuk penghasil jasa apabila tidak dapat memberikan jaminan mutu terhadap proses pendidikan yang diselengarakan, maka lembaga tersebut cenderung tidak akan diminati oleh masyarakat.Masyarkat akan memilih lembaga pendidikan yang dapat memberikan kebutuhan akan pengembangan ilmu pengetahuan dan teknologi serta mempu memberikan layanan pendidikan yang baik/bermutu.

Perguruan Tinggi menjadi bagian yang tidak dapat dipisahkan untuk selalu membekali lembaganya dengan jaminan mutu. Di negara maju, seperti Eropa dan dan negara Timur Tengah antara Perguruan Tinggi dengan Pemerintah selalu bersinergi secara progresif untuk menggunakan sistem manajemen mutu sejak dua dekade terakhir ${ }^{8}$. Fakta ini secara tidak lansung menjelaskan bahwa menghadirkan pendidikan tinggi yang bermutu merupakan suatu keniscayaan agar keberadaan perguruan tinggi tersebut dapat menghasilkan lulusan yang bermutu untuk dapat berkiprah di masyarakat lokal, nasional, dan internasional.

\footnotetext{
${ }^{8}$ Hodson, P. \& Thomas, H. Quality Assurance in Higher Education: Fit for the new millennium or simply year 2000 compliant? Higher Education 45: 375-387. 2003.
} 
Oleh karena itu penerapan manajemen mutu yang baik pada perguruan tinggi akan memberikan kontribusi riil pada kemajuan suatu bangsa. Perguruan tinggi yang bermutu akan memiliki pengaruh positif pada semua sivitas akademik, masyarakat, maupun negara. Bukti konkret atas fenomena ini dapat dilihat pada negara-negara maju. Tentu saja dengan melihat bukti di negara maju bukan berarti harus mengambil semua segala apa yang terjadi di negara maju, perilaku selektif harus dijaga karena setiap negara memiliki budaya yang bervareasi dan harus dijaga agar tidak menghilangkan jati diri negara tersebut.

\section{Quality Control dan Total Quality Management}

Pemahaman yang lebih rinci suatu konsep dapat dilakukan salah satu diantaranya adalah dengan mengetahui unsur atau elemen yang terdapat dalam konsep tersebut. Agar pemahaman mengenahi quality control dapat lebih detail maka perlu dipaparkan element yang menyusun konsep quality control. Pengetahuan yang baik mengenahi suatu konsep akan memudahkan bagi siapa saja yang bermaksud untuk menerapkan konsep tersebut. Memahami element quality control bertujuan agar mudah untuk diterapkan pada ranah praktis. Secara teoritis quality controlberhubungan dengan kualitas manajemen yang baik atau dikenal dengan istilah Total Quality Management (TQM)

Pada dasarnya TQM adalah suatu pendekatan manajemen untuk memberikan layanan yang prima sehingga konsumen dapat mendapatkan kepuasan yang maksimal, sedangkan produsen dapat mendapatkan keuntungan yang optimum. Secara konseptual element dari TQM adalah (1) ethics, (2) integrity, (3) trust, (4) training, (5) teamwork, (6) leadership, (7) recognition, dan (8) communications $^{9}$. Penjelasan grafis element-element yang terdapat dapat pada TQM dapat dilihat pada gambar 1. Adapun delapan element TQM dapat dijelaskan sebagai berikut :

1. Ethics/Kode Etik, merupakan poin-poin pernyataan yang dilakukan sebagai acuan untuk bertindak dan berperilaku setiap anggota dalam suatu organisasi sehingga kesatuan gerak dan perilaku semua anggota

${ }^{9}$ Op.cit.,. Isixsigma. hlm 2. 
dapat terjaga. Biasanya kode etik berisi norma atau moral. Misalnya kode etik dosen, kode etik guru, kode etik dokter atau profesi lainnya.

2. Integrity/Integritas, adalah suatu konsep berkaitan dengan konsistensi dalam tindakan-tindakan, nilai-nilai, metode-metode, ukuran-ukuran, prinsip-prinsip, ekspektasi-ekspektasi dan berbagai hal yang dihasilkan. Orang berintegritas berarti memiliki pribadi yang jujur dan memiliki karakter kuat. Lembaga akan mudah berkembang apabila diisi oleh orang-orang yang berintegritas.

3. Trust/Kepercayaan, adalah tanggapan konsumen secara psikologis terhadap out-put/hasil dari suatu lembaga. Trust yang besar akan mengarahkan kepada pengguna untuk memakai produk baik berupa barang maupun jasa. Membangun kepercayaan sama pentingnya dengan menghasilkan produk itu sendiri. Lembaga dengan memiliki kepercayaan publik yang tinggi akan mudah untuk mendapatkan manfaat secara optimal dari publik.

4. Training/Latihan, yakni mengembangankan SDM yang dimiliki oleh lembaga untuk meningkatkan kemampuannya. Melalui latihan yang berkesinambungan maka SDM akan memiliki rasa percaya diri dan penuh inisiatif untuk mengembangkan lembaga. SDM yang trampil akan memberikan kontribusi mutu yang lebih tinggi dari out-put yang dihasilkan lembaga.

5. Teamwork/Tim kerja, adanya tim kerja dalam lembaga maka akan dapat mengontrol kualitas kerja yang dilakukan oleh SDM. Kerjasama dalam tim akan mempermudah tercapainya tujuan lembaga dan dapat meningkatkan kinerja SDM secara individu. Pekerjaan yang berat, banyak, dan sulit akan terasa ringan, terjangkau, dan mudah apabila kerjasama dalam tim dapat terwujud dalam suatu lembaga.

6. Leadership/Kepemimpinan, faktor ini merupakan faktor kunci karena apabila kepemimpinan berjalan dengan baik maka akan memperlancar terwujudnya TQM. Kepemimpinan yang lemah biasanya akan terjadi pemborosan SDM dan pada saat yang sama terdapat SDM yang overload 
dalam bekerja. Pemborosan tim dapat dirasakan adanya SDM yang tidak terlibat dalam proses sehingga berkurangnya rasa memliki terhadap lembaga dimana SDM tersebut bernaung. Kepemimpinan yang kuat dapat dilihat dari efisiensi SDM, distribusi kerja yang merata, rencana yang matang, dan tercapainya target-target secara terukur.

7. Recognition/Pengakuan, kerja yang dilakukan oleh SDM dalam lembaga perlu adanya apresiasi dari pimpinan. SDM yang jarang mendapatkan pengakuan dari pimpinan atas prestasi kerjanya akan menyebabkan turunnya kinerja. Kinerja yang turun akan berdampak buruk terhadap keberlangsungan lembaga, jika itu yang terjadi maka pimpinan memiliki kontribusi terhadap kesehatan lembaga yang dipimpinnya.

8. Communications/Komunikasi, yakni cara berhubungan antara pimpinan dengan SDM yang ada dalam membahas persoalan-persoalan yang terkait dengan barang maupun jasa sebagai out-put dari lembaga. Ditunjukan pada gambar 1 bahwa komunkasi yang melindungi. Komunkasi berfungsi sebagai dinding, fondasi dan atap. Pimpinan yang baik, akan selalu menjaga cara berkomunikasi dengan SDM. Pimpinan akan memilih kata-kata yang bijaksana untuk memberi saran, masukan, maupun perintah kepada SDM.

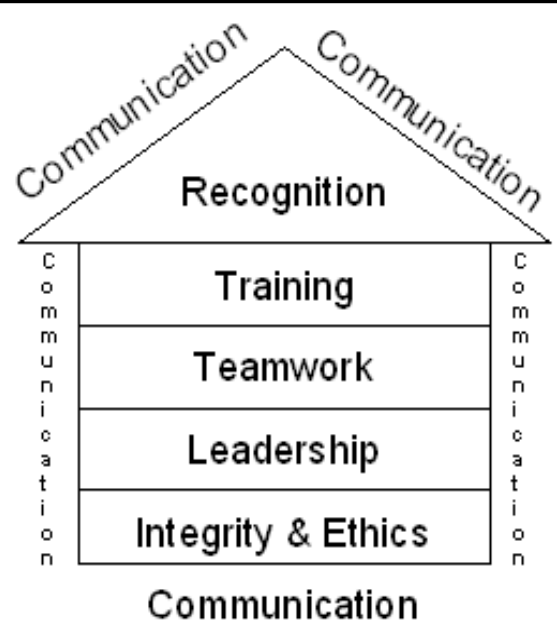

Gambar 1 : Fungsi dan kedudukan elemen TQM 
TQM akan memperlancar dari proses pelaksanaan quality control, dan dapat menghndari overleaping dalam penerapannya. Kaitan antara TQM dengan quality control dapat dilihat pada gambar 2. Berdasarkan gaambar 2 dapat diambil pengertian bahwa quality controlmerupakan bagian dari TQM, sedangkan TQM tidak dapat terwujud apabila tidak ada quality controldalam sistem manajemen. Dengan demikian pelaksanaan quality controlmerupakan bagian yang tidak dapat dipisahkan dengan TQM.

Menurut Kay Abel dan Michael Gillenwater untuk menerapkan quality control dapat dilakukan dengan beberapa langkah, yaitu (1) menginventarisasi kualitas yang diharapkan, (2)menyusun dan melaksanakan rencana kegiatan quality control, (3)membuat prosedur umum tentang pelaksanaan quality control, (4) menentukan kategori yang spesifik mengenahi mutu suatu produk barang dan jasa, (5)memberikan penilaian secara berkala terhadap prosedur pelaksannan quality control dan (6) menentukan prosedur laporan, dokumentasi, dan pengarsipan ${ }^{10}$. Delapan langkah tersebut merupakan serangkaian kegiatan yang dilaksanakan dalam rangka menghadirkan produk maupun layanan yang dapat terjaga kualitasnya. Konsistensi pada delapan langkah tersebut akan memberikan iklim kondusif bagi pihak-pihak yang bertanggungjawab menghasilkan produk layanan dengan kualitas baik.
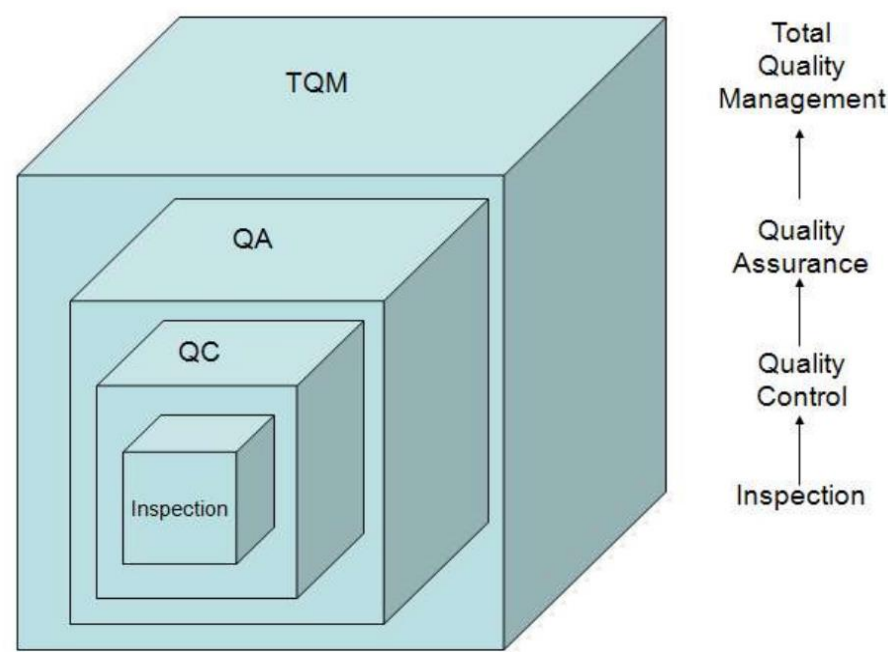

${ }^{10}$ Kay Abel \& Michael Gillenwater. Quality Assurance And Quality Control. Macmillan : New York. 
Gambar 2 : Hubungan Quality Control dan Total Quality Management

\section{Quality Controldan Total Quality Managementpada Pendidikan}

Lembaga pendidikan merupakan bagian yang tidak terpisahkan dari upaya untuk memberikan layanan yang berkualitas. Kualitas suatu lembaga pendidikan salah satu diantaranya ditunjukkan dengan kepercayaan masyarakat untuk mencari ilmu pengetahuan pada lembaga tersebut. Kemampuan lembaga pendidikan dalam memberikan mutu layanan pendidikan sangat tergantung dari sivitas akademik yang dimiliki. Sivitasakademik yang berkualitas akan mampu memberikan mutu layanan pendidikan, masyarakat yang mencari ilmu pada lembaga tersebut akan mendapatkan kepuasan, dan pada akhirnya semakin banyak masyarakat yang percaya pada mutu layanan pendidikan lembaga tersebut.

Keinginan lembaga pendidikan untuk dapat menarik masyarakat secara luas agar bersedia menimba ilmu pada lembaga pendidikan tertentu tidak dapat terwujud apabila masih menggunakan pola manajemen lama. Lembaga pendidikan tersebut harus mengambil pola manajemen baru agar dapat menentukan strategi bagaimana cara untuk mendorong masyarakat menjadi bagian dari lembaganya. Manajemen pola lama bukan berarti salah, akan tetapi sudah tidak relefan dan kontekstual dengan situasi yang ada sekarang ini. Penerapan pola manajemen baru merupakan keniscayaan untuk menjawab permasalahan masakini, dalam kaitannya dengan mengembangkan lembaga pendidikan.

Terdapat 14 tips untuk mengembangkan lembaga pendidikan ${ }^{11}$, yaitu (1) menentukan tujuan yang konsisten, (2) memakai dasar filosofis yang baru, (3) melihat setiap persoalan dengan sudut pandang pengguna, (4) memberi peluang untuk menerapkan ilmu yang telah diperoleh, (5) selalumengembangkan diri, (6) mengadakan pelatihan untuk setiap SDM, (7) menitikberatkan pada kepemimpinan lembaga, (8) mengelola kekhawatiran, (9) menyelesaikan setiap hambatan, (10) membangun semangat dengan tujuan dan slogan, (11) tidak lupa

${ }^{11}$ Robert C. Winn \& Robert S. Green. Applying Total Quality Management to theEducational Process. TEMPUS Publications. 1997. hlm. 25-28. 
diri dengan pujian, (12) menjadikan hambatan sebagai penyemangat diri, (13) melibatkan setiap komponen organisasi, dan (14) menerapkan manajemen secara bertanggungjawab.

Point-point di atas merupakan langkah yang seharusnya dipahami secara operasional, sehingga menuntut aplikasi secara riil. Persoalan yang ditemukan pada tingkat aksi akan selalu diiringi dengan reaksi berupa solusi atas permasalahan yang ada. Semakin jauh aksi yang dilakukan akan menunjukkan hasil yang selalu meningkat. Seiring berjalannya waktu maka keberhasilan secara kumulatif akan kelihatan menuju ke arah yang lebih baik.

Sistem manajemen mutu pada perguruan tinggi sangat perlu untuk mendapatkan perhatian. Pada pendidikan tinggi setiap pimpinan dan SDM yang lain selalu berusaha untuk menemukan sistem manajemen mutu agar para mahasiswa mendapat pelayanan yang memuaskan. Perlu dipikirkan suatu konsep yang mengarah pada peningkatan aktifitas secara terus menerus ${ }^{12}$. Capaian yang telah diperoleh pada tahun kemarin, harus di evaluasi dan diperbaiki demi peningkatan capaian pada tahun sekarang. Adapun capaian tahun sekarang menjadi modal untuk peningakatan capaian pada tahun yang akan datang, dengan demikian capaian ini dapat berupa suatu fase yang membedakan capaian pada tiap periode dengan kenaikan yang positif.

Terciptanya sistem manajemen mutu pada perguruan tinggi merupakan tanggungjawab seluruh sivitas akademik. Salah satu prinsip yang disaraankan oleh The United Nations Global Compact adalah adanya prinsip partnership ${ }^{13}$. Prinsip ini menegaskan bahwa dalam manajemen tidak ada sosok pemimin yang paripurna, setiap individu memiliki kemampuan yang beragam dan spesialisasi yang berbeda-beda, oleh karena itu prinsip partnership yang dapat mendekatkan setiap kemampuan yang dimiliki oleh SDM. Implikasi dari pemahaman ini adalah setiap SDM dimotivasi oleh pimpinan untuk dapat bekerja dengan lebih baik agar capaian dapat terus membaik dan meningkat, akan tetapi setiap SDM tidak

\footnotetext{
${ }^{12}$ Armand Faganel \& Slavko Dolinšek. Quality Management Systems in Higher Education. hlm. 245. 2010. Naskah tidak diterbitkan.

${ }^{13}$ Anne Graham, eds. The principles for responsible management education. Publisher UN Global Compact : New York. hlm 25. 2007
} 
dituntut untuk memiliki peran yang sama. Pimpinan menentukan standar kerja SDM bukan membatasi cara kerja SDM. Cara ini dapat memungkinkan terbangun SDM yang kreatif dalam mengelola pendidikan tinggi.

Bidang garap yang harus dilakukan pada pendidikan tinggi teramat banyak dan luas, oleh karena itu pemisahan tanggung jawab, pemilihan personal, dan skala prioritas perlu dilakukan dengan sebaik-baiknya. Ada beberapa bidang garap yang strategis untuk dilakukan ${ }^{14}$, yakni (1) strategi, evaluasi, dan manajemen mutu, (2) proses pembelajaran, (3) penelitian, (4) pengembangan SDM, (5) aktifitas mahasiswa, (6) menyediakan infrastruktur, (7) sistem keuangan, dan (8) membuka kerja sama seluas-luasnya dengan berbagai pihak dalam upaya mengembangkan kampus.

Bidang garap pada tingkat teknis pelaksanaan dapat disesuaikan skala prioritas maupun cakupannya. Penyesuaian ini didasarkan pada kemampuan dan kebutuhan lembaga pendidikan. Bidang garap tersebut dapat juga dilakukan dalam beberapa periode, misalnya periode pendek, periode menengah maupun perode panjang. Sebagai contoh bidang garap penelitian termasuk periode pendek, bidang garap pengembangan SDM termasuk periode menengah, dan menyediakan infrastruktur termasuk periode panjang.

\section{E. Pentingnya Quality Controldan Total Quality Management Bagi Pendidik}

Jaminan mutu dan sistem manajemen tidak hanya berorientasi pada institusi, akan tetapi jaminan mutu dan sistem manajemen harus memperhatikan SDM yang menyelenggarakan pendidikan di kelas/ ruang kuliah yaitu guru maupun dosen. Menurut penulis ada 4 hal yang diperhatikan dalam penjaminan mutu dan manajemen bagi pendidik, yaitu (1) etika, (2) komitmen, (3) bidang kerja, dan (4) deskripsi kerja. Setiap komponen dapat dijelaskan sebagai berikut :

\section{Etika}

Pendidik merupakan tenaga profesional, setiap tenaga profesional memiliki kode etik yang harus diperhatikan. Melanggar kode etik akan merusak citra profesi yang bersangkutan. Memahami kode etik adalah keniscayaan bagi

\footnotetext{
${ }^{14}$ Op.cit., Armand Faganel \& Slavko Dolinšek. hlm 248.
} 
pendidik agar dalam menjalankan tugasnya tetap dalam bingkai etika yang telah ditentukan. Menurut the National Association for the Education of Young Children, rumusan kode etik untuk pendidik dapat bervareasi, akan tetapi selalu bersumber pada nilai utama (core value $)^{15}$. Adapun core value yang dimaksud adalah:

a. Menyadari bahwa pendidikan adalah mengarahkan individu yang sedang tumbuh, oleh karena itu memberikan apresiasi adalah hal yang diutamakan.

b. Mendidik berdasarkan pengetahuan.

c. Menyadari bahwa apresiasi dan pemberian bantuan adalah tulang punggung pembelajaran.

d. Memahami bahwa setiap individu akan memiliki pemahaman yang baik tergantung dari pendidik, lingkungan, budaya dan keluarga.

e. Menghormati dan menghargai adanya perbedaan latarbelakang

f. Menyadari bahwa individu memiliki potensi tumbuh dengan baik dengan pemberian pujian dan membangun rasa percaya diri.

Perhatian setiap pendidik akan core value akan memberikan semangat dan motivasi secara internal bagi pendidik untuk senantiasa menjaga kualitas dalam menyelenggarakan pembelajaran. Hal ini secara tidak langsung guru secara pribadi selalu berusaha untuk menjaga mutu dalam menyelenggarakan pendidikan.

\section{Komitmen}

Komitmen merupakan tekat untuk melaksanakan tugas dengan sebaikbaiknya. Pendidik yang memiliki komitmen terhadap pendidikan akan memiliki tekat untuk melaksanakan tugas mendidik dengan mutu yang baik. Komitmen dapat dibuat bersama untuk memberikan kesadaran komunal, akan tetapi komitmen yang disadari secara pribadi akan lebih baik karena dapat menyatu dengan kepribadian seorang pendidik.

\footnotetext{
${ }^{15}$ The National Association for the Education of Young Children. Code of Ethical Conductand Statement of Commitment. Washington DC. 2005. hlm. 1
} 
Pendidik akan memiliki level komitmen yang tinggi apabila berusaha bekerja secara maksimal, terikat secara emosional dengan lembaga tempat bekerja, dan berusaha keras untuk mencapai tujuan pembelajaran ${ }^{16}$. Manajemen mutu akan lebih mudah untuk mencapai tujuan yang telah ditentukan apabila pendidik dalam suatu lembaga memiliki komitmen yang baik. Penyelenggaraan pendidikan akan menjadi lebih bermutu ditangan pendidik yang berkomitmen.

Karakteristik pendidik yang berkomitmen dapat terlihat pada konsen pada upaya menyelenggarakan pembelajaran dengan berbagai pendekatan, mengevaluasi capaian dalam pembelajaran baik peserta didik maupun capaian dirinya, menyajikan materi dan menjelaskan dengan baik, dan memberi kemudahan peserta didik dalam memaham materi melalui berbagai pendekatan belajar $^{17}$.

\section{Bidang Kerja}

Bidang kerja yang dimaksud adalah tugas tambahan yang diberikan pimpinan pada pendidik. Setiap pendidik memiliki potensi yang berbeda-beda. Tidak setiap pendidik siap untuk mengerjakan tugas yang diberikan pimpinan. Pemimpin sebaiknya mengetahui potensi dan kemampuan pendidik. Tugas yang sesuai maka cenderung akan di lakukan dengan full power, sehingga hasilnya relatif lebih baik dari pada tugas yang tidak sesuai.

Upaya untuk mengurangi kesalahan dalam memberikan tugas, maka sebagai pimpinan sebaiknya melakukan analisis tugas. Setelah tugas dianalisi kemudian mencermati SDM yang akan diberi tugas tersebut. Proses ini dilakukan secara obyektif dan transparan agar terhindar dari sifat like and dislike. Dengan demikian tugas akan dilaksanakan oleh SDM yang tepat sehingga mutu dari pelaksanaan tugas dapat lebih terjamin.

\section{Deskripsi Kerja}

Setiap pekerjaan memerlukan penjelasan yang baik. Deskripsi kerja yang jelas akan memudahkan dalam menyelesaikan. Deskripsi juga akan mengurangi celah perbedaan antara pimpinan dengan SDM yang mengerjakan tugas. Manfaat

\footnotetext{
${ }^{16}$ Çağrı Tuğrul Mart. Commitment to School and Students. International Journal of Academic Research in Business and Social Sciences. January 2013, Vol. 3, No. 1.

${ }^{17}$ Ibid, Çağrı Tuğrul Mart. hlm. 338.
} 
dari deskripsi kerja antara lain dapat menjadikan iklim kerja yang harmoni, SDM lebih merasa nyaman dalam proses kerja.

Apabila jenis pekerjaan tersebut ada kaitannya dengan batas waktu, ketentuan atau tahapan lain maka hal-hal tersebut sudah semestinya disampaiakan dan ditekankan dengan baik pada awal pemberian tugas atau pekerjaan agar tidak terjadi perbedaan persepsi. Proses ini disebut dengan analisis tugas. Analisis tugas dapat dipahami dengan usaha pencarian informasi yang berhubungan dengan pekerjaan, kemudian mengorganisis dalam suatu urutan yang logis. Dengan demikian pimpinan dan SDM dapat berkhidmat untuk menjalankan setiap tugas yang diembannya dengan penuh rasa tanggung jawab.

\section{F. Simpulan}

Berdasarkan uraian di atas dapat disimpulkan bahwa dalam mengelola organisasi pendidikan harus dilakukan dengan sebaik mungkin. Apabila lembaga pendidikan kurang baik, maka masyaraakat tidak akan memberikan respon terhadap lembaga tersebut dan pada akhirnya lembaga tersebut ditinggalkan ole msyarakat.

Usaha untuk mewujudkan mutu lembaga pendidikan adalah dengan quality control dan total quality management. Keduanya telah terbukti secara empiris dapat menjadikan lembaga pendidikan menjadi sangat bermutu dan menjadi pilihan masyarakat, karena masyarakat merasa kebutuhan akan ilmu pengetahuan dapat terpenuhi dengan lembaga pendidikan tersebut.

Quality control dan total quality managementmerupakan metode global yang didalamnya banyak terdapat tahapan maupun proses yang harus diterapkan agar hasilnya dapat dirasakan oleh lembaga pendidikan. Penerapan quality control dan total quality managementmemerlukan pimpinan dan SDM yang menggunakan konsep manajement baru. 


\section{Daftar Pustaka}

Anne Graham, eds. The principles for responsible management education. Publisher UN Global Compact : New York. 2007

Armand Faganel \& Slavko Dolinšek. Quality Management Systems in Higher Education. hlm. 245. 2010. Naskah tidak diterbitkan.

Çağrı Tuğrul Mart. Commitment to School and Students. International Journal of Academic Research in Business and Social Sciences. January 2013, Vol. 3, No. 1.

Didin Saripudin. Pembangunan Prndidikan dan Pertumbuhan Ekonomi Indonesia. Makalah disajikan dalam International Seminar on Lifelong Education (ISLE), Tanggal 22-23 Agustus 2008 di Universitas Pendidikan Indonesia, Bandung.

Hasbullah. Guru Bersertifikasi Versus Profesionalisme Guru : Tinjauan Kritis Terhadap Pelaksanaan Sertifikasi Guru. Jurnal Pendidikan Teknik Elektro. UPI Bandung. 2010.

Hodson, P. \& Thomas, H. Quality Assurance in Higher Education: Fit for the new millennium or simply year 2000 compliant? Higher Education 45: 375-387. 2003.

http://www.qualitygurus.com/courses/mod/forum/discuss.php?d=1557

https://www.isixsigma.com.

Kay Abel \& Michael Gillenwater. Quality Assurance And Quality Control. Macmillan : New York. 2001

Robert C. Winn \& Robert S. Green. Applying Total Quality Management to the Educational Process. TEMPUS Publications. 1997.

Scottish Qualifications Authority. Quality Assurance Principles, Elements and Criteria. Published by the Scottish Qualifications Authority. 1998. hlm. 10.

Suzanne M Wilson \& Penelope L Peterson. Theories of Learning and Teaching What Do They Mean for Educators?. National Education Assosiaton. Washington DC.2006.

The National Association for the Education of Young Children. Code of Ethical Conduct and Statement of Commitment. Washington DC. 2005. hlm. 1 
Undang-undang No 14 Tahun 2005 tentang Guru dan Dosen. 